\title{
PENGARUH KUALITAS PELAYANAN DAN PROMOSI TERHADAP KEPUASAN PELANGGAN FARMERS MARKET KALIBATA CITY (Studi Kasus Pada Perusahaan Sektor Retail Farmers Market Kalibata City)
}

\author{
${ }^{1 *}$ Tujilas Agustin, ${ }^{2}$ Fadillah \\ Universitas Pamulang, Tangerang Selatan, Banten, Indonesia \\ *dosen02197@unpam.ac.id
}

\begin{abstract}
Abstrak
Tujuan penelitian ini adalah untuk mengetahui pengaruh kualitas pelayanan terhadap kepuasan pelanggan, untuk mengetahui Pengaruh Promosi terhadap Kepuasan Pelanggan, untuk mengetahui Pengaruh Kualitas Pelayanan dan Promosi terhadap Kepuasan Pelanggan Pada Farmers Market Kalibata City. Jenis penelitian yang digunakan dalam skripsi ini adalah metode kuantitatif asosiatif dengan 97 sampel penelitian. Hasil pengujian hipotesis pertama diperoleh nilai $t$ hitung $>t$ tabel $(7.342$ $>1,98525)$ Hal tersebut juga diperkuat dengan nilai Sig. $<0,05$ atau $(0,000<0,05)$. Dengan demikian maka H0 ditolak dan H1 diterima, hal ini menunjukkan bahwa secara parsial variabel Kualitas Pelayanan terdapat pengaruh signifikan terhadap Kepuasan Pelanggan pada Farmers Market Kalibata City. Berdasarkan pada hasil pengujian hipoteisis kedua diperoleh nilai $t$ hitung $>\mathrm{t}$ tabel atau $(7.131>$ 1,98525), hal tersebut juga diperkuat dengan nilai Sig. $<0,05$ atau $(0,000<0,05)$. Dengan demikian maka H0 ditolak dan H2 diterima, hal ini menunjukkan bahwa secara parsial variabel Promosi terdapat pengaruh signifikan terhadap Kepuasan Pelanggan pada Farmers Market Kalibata City. Berdasarkan pada hasil pengujian hipotesis ketiga diperoleh nilai Fhitung $>$ Ftabel atau $(41.180>3,09)$, hal ini juga diperkuat dengan $\rho$ value $<$ Sig. 0,05 atau $(0,000<0,05)$. Dengan demikian maka H0 ditolak dan H3 diterima, hal ini menunjukkan bahwa secara simultan variabel Kualitas Pelayanan dan Promosi terdapat pengaruh signifikan terhadap Kepuasan Pelanggan pada Farmers Market Kalibata City.
\end{abstract}

Kata Kunci: Kualitas Pelayanan, Promosi, Kepuasan Pelanggan

\section{Abstract}

The purpose of this study was to determine the effect of service quality on customer satisfaction, to determine the effect of promotion on customer satisfaction, to determine the effect of service quality and promotion on customer satisfaction at the Kalibata City Farmers Market. The type of research used in this thesis is associative quantitative method with 97 research samples. The results of testing the first hypothesis obtained the value of $t$ arithmetic $>t$ table $(7.342>1.98525)$. This is also reinforced by the value of Sig. $<0.05$ or $(0.000<0.05)$. Thus, $\mathrm{HO}$ is rejected and H1 is accepted, this shows that partially the Service Quality variable has a significant influence on Customer Satisfaction at the Kalibata City Farmers Market. Based on the results of the second hypothesis testing, the value of t arithmetic $>t$ table or $(7.131>1.98525)$, is also strengthened by the value of Sig. $<0.05$ or $(0.000<0.05)$. Thus, $\mathrm{HO}$ is rejected and $\mathrm{H} 2$ is accepted, this shows that partially the Promotion variable has a significant influence on Customer Satisfaction at the Kalibata City Farmers Market. Based on the results of testing the third hypothesis, it is obtained that the value of Fcount > Ftable or $(41.180>3.09)$, this is also strengthened by value < Sig. 0.05 or $(0.000<0.05)$. Thus, $\mathrm{HO}$ is rejected and H3 is accepted, this shows that simultaneously the variables of Service Quality and Promotion have a significant influence on customer satisfaction at the Kalibata City Farmers Market.

Keywords: Service Quality, Promotion, Customer Satisfaction

\section{PENDAHULUAN}

Meningkatnya

masyarakat berarti juga meningkatnya persaingan diantara perusahaanperusahaan yang akan memenuhi kebutuhan-kebutuhan masyarakat tersebut.
Persaingan dalam industri Supermarket untuk memperebutkan calon pelanggan dan mempertahankan pelanggan yang sudah ada merupakan tantangan yang sangat berat dan harus di hadapi oleh 
perusahaan untuk tetap bertahan dalam dunia pemasaran.

Perusahaan yang ingin bertahan harus memiliki keunggulan-keunggulan tersendiri yang akan menjadikan nilai plus bagi perusahaan tersebut dimata perusahaan lain. Pemasaran yang baik dapat terlihat dari adanya saling ketergantungan antara konsumen dengan produsen sedangkan pemasaran yang tidak baik terlihat dari tidak adanya ketergantungan antara kedua belah pihak tersebut.

Kualitas pelayanan dan promosi yang baik merupakan faktor kunci yang memiliki pengaruh besar bagi keberhasilan suatu perusahaan dan menjadi Faktor penentu kepuasan pelanggan. Kualitas pelayanan dan promosi menjadi sangat penting untuk memenangkan persaingan dengan memahami apa yang diinginkan dan diharapkan oleh konsumen dari kualitas pelayanan yang diberikan.

Industri retail merupakan industri yang strategis dalam kontribusi nya terhadap perekonomian Indonesia. Dalam konteks global, potensi pasar retail tergolong cukup besar. Industri retail memiliki kontribusi terbesar kedua terhadap pembentukan Gross Domestic Product (GDP) setelah industri pertanian. Selain itu, dilihat dari sisi pengeluaran, GDP yang di potong oleh pola konsumsi juga memiliki hubungan erat dengan industri retail. Hal inilah yang diyakini menjadi daya dorong pemulihan pertumbuhan ekonomi Indonesia pasca krisis tahun 1998, (Saidini dan Arifin,2012).

Pada tahun 2015 mulai dibuka pasar bebas ASEAN, bukan hanya masyarakat dari negara asean yang akan masuk ke negara Indonesia, namun juga ritel dari negara-negara ASEAN. Sehingga secara demografi, retail modern semakin dibutuhkan oleh masyarakat dimana seharusnya dalam iklim bisnis pasar bebas semua pihak bersaing secara sehat memberikan yang terbaik kepada konsumen, (Gifar,2015).

Sekjen Asosiasi pengusaha retail Indonesia (Apriando), Solihin, mengungkapkan bahwa pertumbuhan pasar retail Indonesia tahun 2015 akan berat karena beberapa faktor ekonomi tidak mendukung. Menurut Solihin, penyebab perlambatan usaha ritel tahun adalah kinerja ekonomi Indonesia yang lesu dalam beberapa tahun terakhir, bahkan hingga kuartal 1 tahun ini. Hal tersebut menyebabkan daya beli konsumen sedikit melemah.

Perkembangan pusat perbelanjaan sekarang diikuti oleh munculnya pusat perbelanjaan modern, termasuk Farmers Market Kalibata City. Pada tahun 2007, PT. Supra Boga Lestari melihat ada peluang untuak mengembangkan pasar baru dan menggarap segmen kelas menengah atas, dengan memperkenalkan konsep supermarket yang lain yaitu "Pasar Petani".

Pasar petani merupakan format baru dibidang supermarket yang memiliki luas lebih besar, juga menyediakan bermacammacam produk lokal yang lebih lengkap dan beragam, dengan tetap menitikberatkan pada produk-produk segar dan kualitas produk yang tinggi serta pelayanan yang prima bagi pelanggannya. Kemampuan perusahaan dalam memberikan pelayanan merupakan salah satu penentu keberhasilan suatu perusahaan.

Pengelola dan jajaran dari Farmers Market Kalibata City harus memiliki keseragaman aksi dalam upaya memberikan pelayanan yang terbaik bagi pelanggan sehingga dapat meningkatkan kepuasan pelanggan dalam membeli produk yang tersedia Farmers Market Kalibata City. Pelanggan adalah prioritas utama, komplain adalah masalah, tapi ini memberi kesempatan bagi perusahaan untuk memperbaiki apa yang memang harus di perbaiki.

Semakin berkembangnya kemajuan internet, media sosial, dan teknologi lainnya, pelanggan menjadi lebih memahami objek yang dapat memberikan kepuasan bagi pelanggan. Kepuasan pelanggan menjadi kunci utama keberhasilan perusahaan dalam menjalankan usaha yang dilakukan. Hal 
inipun mempengaruhi penjualan Farmers Market selama 3 (tiga) tahun terakhir yang mengalami peningkatan cukup signifikan.

Selama 3 tahun terakhir, Farmers Market Kalibata City mampu mengoptimalkan penjualannya dan memberikan kontribusi yang positif bagi

Tabel 1. Laporan Penjualan Farmers Market Kalibata City 2018-2020

perkembangan perusahaan. Hal ini dapat dilihat pada tabel 1. laporan penjualan Farmers Market dengan tingkat penjualan yang hampir memenuhi target penjualan per-tahun. Adapun data laporan penjualan Farmers Market Kalibata City dapat dilihat pada tabel 1., sbb:

\begin{tabular}{|c|c|c|c|c|c|c|c|c|c|c|}
\hline \multirow{2}{*}{ No. } & \multirow{2}{*}{ DEP NAME } & \multicolumn{3}{|c|}{2018} & \multicolumn{3}{|c|}{2019} & \multicolumn{3}{|c|}{2020} \\
\hline & & Sales & Target & $\%$ & Sales & Target & $\%$ & Sales & Target & $\%$ \\
\hline 1 & Grocery & 30.616 & 35.266 & $87 \%$ & 31.444 & 32.330 & $97 \%$ & 31.634 & 30.026 & $105 \%$ \\
\hline 2 & Non Food & 14.341 & 14.480 & $99 \%$ & 15.513 & 15.152 & $102 \%$ & 16.036 & 14.766 & $109 \%$ \\
\hline 3 & Gms & 6.357 & 7.739 & $82 \%$ & 5.870 & 6.727 & $87 \%$ & 5.986 & 5.621 & $106 \%$ \\
\hline 4 & Fresh & 32.632 & 36.042 & $91 \%$ & 32.584 & 34.576 & $94 \%$ & 33.759 & 34.445 & $98 \%$ \\
\hline \multicolumn{2}{|c|}{ Persentase } & 83.947 & 93.527 & $90 \%$ & 85.411 & 88.785 & $96 \%$ & 87.416 & 84.858 & $103 \%$ \\
\hline
\end{tabular}

Pada tabel 1., laporan penjualan Farmers Market Kalibata City terlihat mengalami perkembangan yang cukup signifikan selama 3 tahun terakhir. Hal ini terlihat dari departemen 'Grocery' pada tahun 2018 dengan tingkat persentase penjualan sebesar $87 \%$ dan mengalami kenaikan sebesar $10 \%$ menjadi $97 \%$ dan di tahun 2020 melampaui target penjualan di angka Rp $31.634 \mathrm{M}$ dengan persentase penjualan sebesar $105 \%$.

Sedangkan pada produk non-food juga mengalami hal yang sama seperti grocery dengan data penjualan pada tahunn 2018 sebesar 99\% dan melampaui target penjualannya pada tahun 2019 sebesar 102\% dan 2020 sebesar 109\%. Peningkatan penjualan yang terjadi pada produk lainnya juga mengalami keadaan serupa. Hal ini menunjukan bahwa aktivitas yang terjadi pada perusahaan tersebut mempengaruhi kepuasaan pelanggan.

Kepuasan pelanggan dapat dipengaruhi oleh beberapa faktor, seperti: kualitas pelayanan, harga (promosi, diskon, dll), orientasi pasar, dan evaluasi yang membuat perusahaan mampu memenuhi kebutuhan yang diinginkan pelanggan. Peter dan Olson, (1999:205) menjelaskan bahwa promosi memperkuat loyalitas perusahaan. Hal ini dikarenakan sebagian pelanggan cenderung membeli suatu produk didasarkan pada promosi dan tawaran lain.

Kepuasan pelanggan dapat dinilai dari banyaknya pelanggan yang setia menjadi pembeli dan melakukan pembelian berulang di perusahaan tersebut. Semakin banyak jumlah pelanggan yang memutuskan pembelian diperusahaan tersebut, maka kualitas pelayanan dan pemasaran yang dilakukan dinilai baik. Sebaliknya, semakin sedikit atau berkurang jumlah pelanggan yang berada diperusahaan tersebut, maka semakin rendah pula kualitas pelayanan dan pemasaran perusahaan tersebut. Selain dari kepuasan, pengaruh promosi juga dapat mempengaruhi meningkatnya penjualan. Berikut adalah data promosi Farmers Market Kalibata City Periode pada setiap tahunnya.

Tabel 2. Data Biaya Promosi Farmers Market Kalibata City 2020

\begin{tabular}{|l|c|c|}
\hline \multicolumn{1}{|c|}{ Jenis Promosi } & Banyak Kegiatan & Biaya Promosi \\
\hline $\begin{array}{l}\text { Penyebaran Iklan Melalui Media } \\
\text { Online/ Sosial }\end{array}$ & 12 & Rp. 1.200 .000 \\
\hline Pemasangan Banner (3 pasang) & 12 & Rp. 2.700 .000 \\
\hline $\begin{array}{l}\text { Kegiatan Pameran Promosi Produk } \\
\text { farmer market setiap akhir pekan }\end{array}$ & 48 & Rp. 14.000 .000 \\
\hline Total Biaya Promosi /Tahun & $\mathbf{7 2}$ & Rp. 17.900.000 \\
\hline
\end{tabular}


Berdasarkan tabel 2 di atas dapat dilihat bahwa promosi yang dilakukan oleh Farmers Market Kalibata City masih belum memberikan pengaruh minat beli dari pelanggan, dilihat pada biaya yang dikeluarkan untuk kegiatan promosi pada

\begin{tabular}{|c|l|c|c|}
\hline No & \multicolumn{1}{|c|}{ Penerapan Promosi } & Ya & Tidak \\
\hline 1 & Data flayer/brosur & $\sqrt{ }$ & \\
\hline 2 & Gratis pengiriman & $\sqrt{ }$ & \\
\hline 3 & Promo aplikasi & & $\sqrt{ }$ \\
\hline 4 & Minimal pembelian & & $\sqrt{ }$ \\
\hline 5 & Potongan harga & $\sqrt{ }$ & \\
\hline 6 & Promo bazar & $\sqrt{ }$ & \\
\hline 7 & Promo purchase with purchase (PWP) & $\sqrt{ }$ & \\
\hline 8 & Buy 1 Get 1 \\
Sumber: Studi Dokumen Peneliti. 2021
\end{tabular}

Berdasarkan tabel 3 di atas dapat dilihat bahwa penerapan promosi yang dilakukan oleh Farmers Market Kalibata City bisa dikatakan efektif dalam mempertahankan tingkat kepuasan pelanggan. Dari data flayer/ brosur yang

Tabel 4. Data Pelanggan Aktif Farmers Market Kalibata City 2018-2020

\begin{tabular}{|c|c|c|c|c|}
\hline \multirow{2}{*}{ Tahun } & Jumlah Pelanggan & Pencapaian & Keterangan \\
\cline { 2 - 3 } & Target & Realisasi & $(\%)$ & Tercapai \\
\hline 2018 & 3000 & 3110 & $103,7 \%$ & Tercapai \\
\hline 2019 & 3200 & 3280 & $102,5 \%$ & Tercapai \\
\hline 2020 & 3400 & 3500 & $102,9 \%$ & Tercapai \\
\hline Rata-rata & 3200 & 3297 & $103,0 \%$ & \\
\hline
\end{tabular}

Berdasarkan tabel 4 jumlah pelanggan aktif di Farmers Market Kalibata City selama 3 tahun (2018-2020) mengalami kenaikan dan pencapaian target jumlah pelanggan aktif tercapai. Jumlah target yang ditetapkan secara keseluruhan menunjukkan jumlah pencapaian tercapai. Tahun 2018 mampu mencapai 3110 pelanggan dari yang ditargetkan yaitu 3000 pelanggan, atau secara keseluruhan mencapai mencapai $103,7 \%$ dari yang targetkan oleh perusahaan. Tahun 2019 mampu mencapai 3280 pelanggan dari yang ditargetkan yaitu 3200 pelanggan, atau secara keseluruhan mencapai mencapai $102,5 \%$ dari yang targetkan oleh perusahaan. Kemudian tahun 2020 mampu mencapai 3500 pelanggan dari yang ditargetkan yaitu 3400 pelanggan, atau secara keseluruhan mencapai mencapai $102,9 \%$ dari yang targetkan oleh perusahaan. Kondisi tersebut diharapkan setiap tahunnya adalah Rp. 17.900.000. Dari pengeluaran untuk biaya promosi tersebut ternyata belum mampu memberikan pencapaian target yang diharapkan perusahaan pada setiap tahunnya. setiap hari disediakan oleh perusahaan, gratis pengiriman yang selalu diterapkan, promo bazar pada setiap akhir tahun, promo purchase with purchase setiap akhir pekan dan buy 1 get 1 hari jumat, sabtu dan minggu (JSM).

tetap stabil di tahun berikutnya dengan tetap. Tingginya tingkat kepuasan pelanggan disinyalir disebabkan oleh harga promosi yang tepat sasaran dan pelayanan yang diberikan sudah optimal sehingga mampu memenuhi kebutuhan dan keinginan pelanggan. Harga promosi merupakan elemen bauran yang dapat meningkatkan jumlah pelanggan dan pendapatan melaui hasil penjualan. Oleh karena itu perusahaan harus dapat menetapkan harga promosi atau jasa pelayanan dengan baik dan tepat sasaran, sehingga minat beli pelanggan meningkat dari hasil produk/jasa yang ditawarkan perusahaan sehingga mendapatkan keuntungan serta meningkatkan jumlah penjualan.

Secara garis besar, dalam mempertahankan kinerja pemasaran yang dilakukan, evaluasi menjadi hal yang penting dalam memaksimalkan usaha yang 
dilakukan Farmers Market Kalibata City. Menunjuk pada kondisi yang dikemukakan diatas maka penulis akan melakukan penelitian dengan judul "Pengaruh Kualitas Pelayanan dan Promosi Terhadap Kepuasan Pelanggan Pada Farmers Market Kalibata City".

\section{TINJAUAN PUSTAKA}

\section{Kualitas Pelayanan}

Menurut Gronroos (dalam Ratminto, 2012:2) "Pelayanan adalah suatu aktivitas atau serangkaian aktivitas yang bersifat tidak kasat mata (tidak dapat diraba) yang terjadi sebagai akibat adanya interaksi antara konsumen dengan karyawan atau halhal lain yang disediakan oleh organisasi pemberi pelayanan yang dimaksudnya untuk memecahkan permasalahan konsumen atau pelanggan".

\section{Promosi}

Menurut Herman Malau (2017:103) mengatakan bahwa: "Promosi adalah bentuk persuasi langsung melalui penggunaan berbagai insentif yang dapat diatur untuk merangsang pembelian produk dengan segera dan atau meningkatkan jumlah yang dibeli pelanggan serta membuat konsumen puas sehingga melakukan pembelian kembali".

3. Kepuasan Pelanggan

Menurut Yazid (2012:55)

“Kepuasan pelanggan adalah ketiadaan perbedaan antara harapan yang dimiliki dan unjuk kerja yang diterima. Apabila harapan tinggi, sementara unjuk kerjanya biasa-biasa saja, kepuasan tidak akan tercapai sangat mungkin pelanggan akan merasa kecewa. Sebaliknya apabila unjuk kerja melebihi dari yang diharapkan maka kepuasan meningkat".

\section{METODE}

Populasi dalam penelitian ini berjumlah 3500 responden Farmer Market Kalibata City. Sampel dalam penelitian ini berjumlah 97 responden dengan menggunakan rumus slovin. Jenis penelitian yang dipakai adalah kuantitatif, dimana tujuannya adalah untuk mengetahui pengaruh antara variabel bebas terhadap variabel terikat baik parsial maupun simultan Dalam menganalisis data digunakan uji instrumen, uji asumsi klasik, regresi, koefisien korelasi, koefisien determinasi dan uji hipotesis.

\section{HASIL DAN PEMBAHASAN}

\section{Analisis Kuantitatif}

Pada analisis ini dimaksudkan untuk mengetahui pengaruh variabel independen terhadap variabel dependen. Adapun hasil pengujian sebagai berikut:

\section{a. Analisis Regresi Linier Berganda}

Uji regresi ini dimaksudkan untuk mengetahui perubahan variabel dependen jika variabel independen mengalami perubahan. Adapun hasil pengujiannya sebagai berikut:

Tabel 5. Hasil Uji Regresi Linier Berganda Variabel Kualitas Pelayanan (X1) dan Promosi (X2) Terhadap Kepuasan Pelanggan (Y)

\begin{tabular}{|c|c|c|c|c|c|c|}
\hline \multicolumn{7}{|c|}{$\begin{array}{c}\text { Terhadap Kepuasan Pelanggan (Y) } \\
\text { Coefficients }^{\mathbf{a}}\end{array}$} \\
\hline & & \multicolumn{2}{|c|}{$\begin{array}{l}\text { Unstandardized } \\
\text { Coefficients }\end{array}$} & \multirow{2}{*}{$\begin{array}{c}\text { Standardized } \\
\text { Coefficients } \\
\text { Beta }\end{array}$} & \multirow[t]{2}{*}{$\mathrm{t}$} & \multirow[t]{2}{*}{ Sig. } \\
\hline & & B & Std. Error & & & \\
\hline \multirow[t]{3}{*}{1} & (Constant) & 16.207 & 2.594 & & 6.247 & .000 \\
\hline & Kualitas Pelayanan & .333 & .073 & .403 & 4.568 & .000 \\
\hline & Promosi & .306 & .071 & .380 & 4.303 & .000 \\
\hline
\end{tabular}

a. Dependent Variable: Kepuasan Pelanggan

Berdasarkan hasil analisis perhitungan regresi linier berganda pada tabel di atas, maka dapat diperoleh persamaan regresi $\mathrm{Y}=$ $16.207+0.333 \mathrm{X}_{1}+0.306 \mathrm{X}_{2}$. Dari persamaan di atas maka dapat disimpulkan sebagai berikut:

a) Nilai konstanta sebesar 16.207 diartikan bahwa jika variabel Kualitas Pelayanan $\left(X_{1}\right)$ dan 
Promosi $\quad\left(\mathrm{X}_{2}\right) \quad$ tidak dipertimbangkan maka Kepuasan Pelanggan (Y) hanya akan bernilai sebesar 16.207 point.

b) Nilai Kualitas Pelayanan $\left(X_{1}\right) 0.333$ diartikan apabila konstanta tetap dan tidak ada perubahan pada variabel Promosi $\left(\mathrm{X}_{2}\right)$, maka setiap perubahan 1 unit pada variabel Kualitas Pelayanan $\left(X_{1}\right)$ akan mengakibatkan terjadinya

b. Analisis Koefisien Korelasi

Analisis koefisien korelasi dimaksudkan untuk mengetahui tingkat kekuatan hubungan dari

Tabel 6. Hasil Uji Koefisien Korelasi Antara Kualitas Pelayanan (X1) dan Promosi (X2) Terhadap Kepuasan Pelanggan (Y)

Model Summary ${ }^{b}$

\begin{tabular}{ll|r|r|r} 
Model & R & R Square & Adjusted R Square & Std. Error of the Estimate \\
\hline 1 & $\mathbf{6 8 3}^{\mathbf{a}}$ & .467 & 456 & 2.36
\end{tabular}

a. Predictors: (Constant), Promosi, Kualitas Pelayanan

b. Dependent Variable: Kepuasan Pelanggan

Sumber : Olah data SPSS 26

Berdasarkan pada hasil analisis koefisien korelasi (r) pada tabel di atas, diperoleh nilai $R$ Koefisien korelasi sebesar 0,683 dimana nilai tersebut berada pada interval 0,600 - 0,799

c. Analisis Koefisien Determinasi

Analisis koefisien determinasi dimaksudkan untuk mengetahui besarnya persentase pengaruh dari

Tabel 7. Hasil Uji Koefisien Determinasi Antara Kualitas Pelayanan (X1) dan Promosi (X2) Terhadap Kepuasan Pelanggan $(Y)$

\section{Model Summary ${ }^{\mathbf{b}}$}

\begin{tabular}{ll|r|r|r} 
Model & R & R Square & Adjusted R Square & Std. Error of the Estimate \\
\hline 1 & $.683^{\mathrm{a}}$ & $\mathbf{. 4 6 7}$ & .456 & 2.36.
\end{tabular}

a. Predictors: (Constant), Promosi, Kualitas Pelayanan

b. Dependent Variable: Kepuasan Pelanggan

Sumber : Olah data SPSS 26

Berdasarkan pada hasil pengujian pada tabel di atas, diperoleh nilai $R$ Square sebesar 0,467 maka dapat disimpulkan bahwa variabel Kualitas Pelayanan dan Promosi berpengaruh terhadap variabel Kepuasan Pelanggan sebesar $46,7 \%$ sedangkan sisanya sebesar (100 - $46,7 \%)=53,3 \%$ dipengaruhi faktor lain yang tidak dilakukan dalam

artinya variabel Kualitas Pelayanan kerja dan Promosi mempunyai tingkat hubungan yang Kuat terhadap Kepuasan Pelanggan.

variabel independen terhadap variabel dependen baik secara parsial maupun simultan. Adapun hasil pengujian sebagai berikut:

kenaikan pada Kepuasan Pelanggan $(Y)$ sebesar 0.333 point. apabila konstanta tetap dan tidak setiap perubahan 1 unit pada Promosi $\left(X_{2}\right)$ akan mengakibatkan kenaikan pada Kepuasan Pelanggan (Y) sebesar 0.306 point. variabel independen terhadap variabel dependen baik secara parsial maupun simultan. Adapun hasil pengujian sebagai berikut: 2.36 
Tabel 8. Hasil Uji Hipotesis Secara Parsial (Uji t) Kualitas Pelayanan (X1) Terhadap Kepuasan

\begin{tabular}{|c|c|c|c|c|c|}
\hline \multirow[b]{3}{*}{ Model } & \multicolumn{2}{|c|}{$\begin{array}{l}\text { Pelanggan (Y) } \\
\text { Coefficients }^{\mathbf{a}}\end{array}$} & \multirow{3}{*}{$\begin{array}{c}\text { Standardized } \\
\text { Coefficients } \\
\text { Beta }\end{array}$} & \multirow{3}{*}{$\mathrm{t}$} & \multirow{3}{*}{ Sig. } \\
\hline & \multicolumn{2}{|c|}{$\begin{array}{l}\text { Unstandardized } \\
\text { Coefficients }\end{array}$} & & & \\
\hline & $\mathrm{B}$ & Std. Error & & & \\
\hline $1 \quad$ (Constant) & 21.905 & 2.428 & & 9.021 & .000 \\
\hline Kualitas Pelayanan & .496 & .068 & .602 & 7.342 & .000 \\
\hline
\end{tabular}

a. Dependent Variable: Kepuasan Pelanggan Sumber : Olah data SPSS 26

Berdasarkan pada hasil pengujian pada tabel di atas diperoleh nilai $t_{\text {hitung }}>t_{\text {tabel }}$ atau $(7.342>1,98525)$ Hal tersebut juga diperkuat dengan nilai Sig. $<0,05$ atau $(0,000<0,05)$. Dengan demikian maka $\mathrm{H}_{0}$ ditolak Tabel 9. Hasil Uji Hipotesis Secara Parsial (Uji t) Promosi (X2) Terhadap Kepuasan Pelanggan $(\mathrm{Y})$

Coefficients $^{\mathrm{a}}$

\begin{tabular}{|c|c|c|c|c|c|c|}
\hline \multirow{3}{*}{\multicolumn{2}{|c|}{ Model }} & \multicolumn{3}{|c|}{ Coefficients $^{\mathrm{a}}$} & \multirow[b]{3}{*}{$\mathrm{t}$} & \multirow[b]{3}{*}{ Sig. } \\
\hline & & \multicolumn{2}{|c|}{$\begin{array}{l}\text { Unstandardized } \\
\text { Coefficients }\end{array}$} & \multirow{2}{*}{$\begin{array}{c}\text { Standardized } \\
\text { Coefficients } \\
\text { Beta }\end{array}$} & & \\
\hline & & $\mathrm{B}$ & Std. Error & & & \\
\hline 1 & (Constant) & 21.692 & 2.529 & & 8.578 & .000 \\
\hline & Promosi & .475 & .067 & .590 & 7.131 & .000 \\
\hline
\end{tabular}

a. Dependent Variable: Kepuasan Pelanggan Sumber : Olah data SPSS 26

Berdasarkan pada hasil pengujian pada tabel di atas diperoleh nilai $t_{\text {hitung }}>t_{\text {tabel }}$ atau $(7.131>1,98525)$ Hal tersebut juga diperkuat dengan nilai Sig. $<0,05$ atau $(0,000<0,05)$. Dengan demikian maka $\mathrm{H}_{0}$ ditolak dan $\mathrm{H}_{2}$ diterima, hal ini menunjukkan bahwa secara parsial variabel Promosi terdapat pengaruh signifikan terhadap Kepuasan Pelanggan pada Farmers Market Kalibata City.

Tabel 10. Hasil Uji Hipotesis Secara Simultan (Uji F) Antara Kualitas Pelayanan (X1) dan Promosi (X2) Terhadap Kepuasan Pelanggan (Y)

\begin{tabular}{|c|c|c|c|c|c|c|}
\hline \multirow{2}{*}{\multicolumn{2}{|c|}{ Model }} & \multicolumn{4}{|c|}{$\mathbf{A N O V A}^{\mathbf{a}}$} & \multirow[b]{2}{*}{ Sig. } \\
\hline & & $\begin{array}{c}\text { Sum of } \\
\text { Squares }\end{array}$ & df & Mean Square & $\mathrm{F}$ & \\
\hline \multirow[t]{3}{*}{1} & Regression & 460.757 & 2 & 230.378 & 41.180 & $.000^{\mathrm{b}}$ \\
\hline & Residual & 525.882 & 94 & 5.594 & & \\
\hline & Total & 986.639 & 96 & & & \\
\hline
\end{tabular}

a. Dependent Variable: Kepuasan Pelanggan

b. Predictors: (Constant), Promosi, Kualitas Pelayanan Sumber: Olah data SPSS 26

Berdasarkan pada hasil pengujian pada tabel di atas diperoleh nilai $F_{\text {hitung }}>F_{\text {tabel }}$ atau $(41.180>3,09)$, hal ini juga diperkuat dengan $\rho$ value $<$ Sig. 0,05 atau $(0,000<0,05)$. Dengan demikian maka $\mathrm{H}_{0}$ ditolak dan $\mathrm{H}_{3}$ diterima, hal ini menunjukkan bahwa secara simultan variabel Kualitas Pelayanan dan Promosi terdapat pengaruh signifikan terhadap dan $\mathrm{H}_{1}$ diterima, hal ini menunjukkan bahwa secara parsial variabel Kualitas Pelayanan terdapat pengaruh signifikan terhadap Kepuasan Pelanggan pada Farmers Market

Kalibata City.

\section{Uji Hipotesis Simultan (Uji F)}

Pengujian hipotesis dengan uji $\mathrm{F}$ digunakan untuk mengetahui hipotesis simultan yang mana yang diterima.

Hipotesis ketiga Terdapat pengaruh yang signifikan antara kualitas pelayanan dan promosi terhadap kepuasan pelanggan.
Kepuasan Pelanggan pada Farmers Market Kalibata City.

\section{PEMBAHASAN HASIL PENELITIAN}

\section{Pengaruh Kualitas Pelayanan Terhadap Kepuasan Pelanggan}

Berdasarkan hasil perhitungan regresi linier sederhana, maka dapat diperoleh persamaan regresi $Y=21.905+$ 0.496 X1. Dari persamaan regresi maka 
dapat disimpulkan baahwa Nilai konstanta sebesar 21.905 diartikan bahwa jika variabel Kualitas Pelayanan (X1) tidak ada maka telah terdapat nilai Kepuasan Pelanggan (Y) sebesar 21.905 point. Nilai koefisien regresi Kualitas Pelayanan (X1) sebesar 0. 496 diartikan apabila konstanta tetap dan tidak ada perubahan pada variabel Promosi (X2), maka setiap perubahan 1 unit pada variabel Kualitas Pelayanan (X1) akan mengakibatkan terjadinya kenaikan pada Kepuasan Pelanggan (Y) sebesar 0. 496 point. Berdasarkan hasil penelitian uji $\mathrm{t}$ diperoleh nilai $\mathrm{t}$ hitung $>\mathrm{t}$ tabel $(7.342>1,98525)$ Hal tersebut juga diperkuat dengan nilai Sig. $<0,05$ atau $(0,000<0,05)$. Dengan demikian maka $\mathrm{H} 0$ ditolak dan $\mathrm{H} 1$ diterima, hal ini menunjukkan bahwa secara parsial variabel Kualitas Pelayanan terdapat pengaruh signifikan terhadap Kepuasan Pelanggan pada Farmers Market Kalibata City.

Hasil tersebut sejalan dengan hasil penelitian Andriasan Sudarso (2016), yang menunjukkan bahwa kualitas pelayanan mempunyai pengaruh yang signifikan terhadap kepuasan pelanggan. Artinya variabel Kualitas Pelayanan terhadap Kepuasan Pelanggan menjadi salah satu hal penting yang dinilai konsumen ketika menggunakan. Apabila kualitas pelayanan yang diberikan perusahaan meningkat, itu akan meningkatkan tingkat kepuasan pelanggan.

2. Pengaruh Promosi Terhadap Kepuasan Pelanggan

Berdasarkan hasil perhitungan regresi pada tabel di atas, maka dapat diperoleh persamaan regresi $Y=21.692+$ 0.475 X2. Nilai konstanta sebesar 21.692 diartikan bahwa jika variabel Promosi (X2) tidak ada, maka telah terdapat nilai Kepuasan Pelanggan (Y) sebesar 21.692 point. Nilai koefisien regresi didiplin kerja (X2) sebesar 0.475 diartikan apabila konstanta tetap dan tidak ada perubahan pada variabel Kualitas Pelayanan (X1), maka setiap perubahan 1 unit pada variabel Promosi (X2) akan mengakibatkan terjadinya kenaikan pada Kepuasan Pelanggan (Y) sebesar 0.475 point. Berdasarkan pada hasil pengujian pada uji $\mathrm{t}$ diperoleh nilai $\mathrm{t}$ hitung $>\mathrm{t}$ tabel atau $(7.131>1,98525) \mathrm{Hal}$ tersebut juga diperkuat dengan nilai Sig. $<0,05$ atau $(0,000<0,05)$. Dengan demikian maka $\mathrm{H} 0$ ditolak dan $\mathrm{H} 2$ diterima, hal ini menunjukkan bahwa secara parsial variabel Promosi terdapat pengaruh signifikan terhadap Kepuasan Pelanggan pada Farmers Market Kalibata City.

Hasil tersebut sejalan dengan hasil penelitian Alelign (2014), yang menunjukkan bahwa promosi mempunyai pengaruh yang signifikan terhadap kepuasan pelanggan. Artinya variabel promosi menjadi salah satu hal yang dinilai konsumen. Apabila promosi yang diberikan perusahaan meningkat, itu akan meningkatkan kepuasan konsumen.

3. Pengaruh Kualitas Pelayanan dan Promosi Terhadap Kepuasan Pelanggan

Berdasarkan hasil analisis perhitungan regresi linier berganda pada tabel di atas, maka dapat diperoleh persamaan regresi $Y=16.207+0.333 X 1+$ 0.306X2. Dari persamaan tersebut maka dapat disimpulkan Nilai konstanta sebesar 16.207 diartikan bahwa jika variabel Kualitas Pelayanan (X1) dan Promosi (X2) tidak dipertimbangkan maka Kepuasan Pelanggan (Y) hanya akan bernilai sebesar 16.207 point. Nilai Kualitas Pelayanan (X1) 0.333 diartikan apabila konstanta tetap dan tidak ada perubahan pada variabel Promosi (X2), maka setiap perubahan 1 unit pada variabel Kualitas Pelayanan (X1) akan mengakibatkan terjadinya perubahan pada Kepuasan Pelanggan (Y) sebesar 0.333 point. Nilai Promosi (X2) 0.306 diartikan apabila konstanta tetap dan tidak ada perubahan pada variabel Kualitas Pelayanan (X1), maka setiap perubahan 1 unit pada variabel Promosi (X2) akan mengakibatkan terjadinya 
penurunan pada Kepuasan Pelanggan (Y) sebesar 0.306 point. Berdasarkan pada hasil pengujian pada $F$ tabel diperoleh nilai Fhitung $>$ Ftabel atau $(41.180>3,09)$, hal ini juga diperkuat dengan $\rho$ value $<$ Sig. 0,05 atau $(0,000<$ $0,05)$. Dengan demikian maka H0 ditolak dan H3 diterima, hal ini menunjukkan bahwa secara simultan variabel Kualitas Pelayanan dan Promosi terdapat pengaruh signifikan terhadap Kepuasan Pelanggan pada Farmers Market Kalibata City.

\section{PENUTUP}

\section{Kesimpulan}

1. Berdasarkan hasil penelitian uji $t$ diperoleh nilai $\mathrm{t}$ hitung $>\mathrm{t}$ tabel $(7.342>$ 1,98525) Hal tersebut juga diperkuat dengan nilai Sig. $<0,05$ atau $(0,000<$ $0,05)$.

2. Berdasarkan pada hasil pengujian pada uji $t$ diperoleh nilai $t$ hitung $>\mathrm{t}$ tabel atau $(7.131>1,98525)$ Hal tersebut juga diperkuat dengan nilai Sig. $<0,05$ atau $(0,000<0,05)$.

3. Berdasarkan pada hasil pengujian pada $\mathrm{F}$ tabel diperoleh nilai $F_{\text {hitung }}>F_{\text {tabel }}$ atau $(41.180>3,09)$, hal ini juga diperkuat dengan $\rho$ value $<$ Sig. 0,05 atau $(0,000<$ $0,05)$.

\section{Saran}

1. Berdasarkan hasil penilaian, dengan memperhatikan jumlah nilai variabel Kualitas Pelayanan pada Farmers Market Kalibata City, indikator terendah adalah no 3 dengan rata-rata skor 3,42 pada pernyataan "Farmer Market Kalibata City yang cepat akrab dengan pelanggan". Maka sebaiknya perusahaan lebih baik lagi dalam memberikan pelayanan kepada pelanggan.

2. Berdasarkan hasil penilaian, dengan memperhatikan jumlah nilai variabel Promosi Pada Farmers Market Kalibata City indikator terendah adalah no 4 dengan rata-rata skor 3,71 pada pernyataan "Cara Farmer Market Kalibata City memberikan informasi promosi menarik lewat Instagram". Maka perusahaan dalam melakukan kegiatan promosi melalui instagram, dalam memberikan informasi harus yang lebih detail agar mudah dipahami pelanggan.

3. Berdasarkan hasil penilaian, dengan memperhatikan jumlah nilai variabel Kepuasan Pelanggan kerja Pada Farmers Market Kalibata City indikator terendah adalah no 7 dengan rata-rata skor 3,79 pada pernyataan "Pelayanan dan merk produk Farmer Market Kalibata City yang berkualitas membuat saya puas". Maka karyawan agar selalu memperhatikan dalam pelayanan dan merk produk, terutama pada saat ada pelanggan datang langsung mengarahkan ke merk produk lain yang sesuai dengan barang yang dicari.

\section{DAFTAR PUSTAKA}

Alma, Buchari. (2014). Manajemen Pemasaran dan Pemasaran Jasa. Bandung: CV Alfabeta.

Anoraga, Pandji (2012). Manajemen Bisnis, Rineka Cipta, Jakarta.

Erlangga, H., et al. (2020). Pharmaceutical Business Competition in Indonesia: A Review. Systematic Reviews in Pharmacy, 11(10), 617-623.

Haque, M. G., et al. (2021). Micro Financial Sharia Non-bank Strategic Analysis: a Study at BMT Beringharjo, Yogyakarta. Budapest International Research and Critics Institute (BIRCIJournal): Humanities and Social Sciences, 4(2), 1677-1686

Hasibuan, Malayu Sp. (2012). Manajemen SDM. Edisi Revisi, Cetakan Ke Tigabelas. Jakarta : Bumi Aksara.

Hasibuan, Malayu SP. (2014). Manajemen Sumber Daya Manusia, Cetakan keempatbelas, Jakarta, Penerbit : Bumi Aksara.

Hurriyati, Ratih. (2011). Bauran Pemasaran dan Loyalitas Konsumen. Bandung: ALFABETHA.

Kasmad, K., et al. (2020). Increasing Community School Interest Through Service Quality, Prices and Promotion 
in Vocational High Schools. Journal of Educational Science and Technology (EST), 6(2).

Kotler, Philip and Kevin Lane Keller, (2016): Marketing Management, 15th Edition New Jersey: Pearson Pretice Hall, Inc.

Kotler, Philip dan Armstrong, Gary. (2012). Principles of Marketing. New Jersey: Prentice Hall.

Kotler, Philip., Keller, Kevin L. (2013). Manajemen Pemasaran, Jilid Kedua, Jakarta: Erlangga.

Maddinsyah, A., et al. (2020). Desain Formulasi Dan Implementasi Bisnis Strategik Dengan Pendekatan Business Model Canvas (BMC) Terintegrasi Kerangka Integrated Performance Management System (IPMS) Pada Koperasi Asperindo. Inovasi, 7(2), 67-76.

Mursid. (2014). Manajemen Pemasaran. Jakarta: Bumi Aksara

Purwanti, Y. (2021). The Influence Of Digital Marketing \& Innovasion On The School Performance. Turkish Journal of Computer and Mathematics Education (TURCOMAT), 12(7), 118-127.

Purwanto, H., et al. (2020). Developing Model of Halal Food Purchase Intention among Indonesian NonMuslim Consumers: An Explanatory
Sequential Mixed Methods Research. Systematic Reviews in Pharmacy, 11(10), 396-407.

Safroni, Drs. K.H.M. Ladzi. (2012). Manajemen dan Reformasi pelayanan publik.

Safroni. (2012) Manajemen dan Reformasi Pelayanan Publik dalam Konteks Birokrasi Indonesia (Teori, Kebijakan, dan Implementasi), Yogyakarta : Aditya Media Publishing.

Stanton, William J. (2012). Prinsip pemasaran, alih bahasa : Yohanes Lamarto, Jakarta : Penerbit Erlangga.

Sugiyono. (2015). Metode Penelitian Kombinasi (Mix Methods). Bandung: Alfabeta

Syobar, K., et al. (2020). The Effect of Service Quality and Price on Purchase Decisions in Woodpecker Coffee in South Jakarta. Solid State Technology, 63(6), 1491-1504.

Terry, George R dan Leslie W. Rue. (2014). Dasar-Dasar Manajemen, penerjemah G.A Ticoalu. Jakarta: PT Bumi Aksara.

Terry, George R. (2012). Prinsip-Prinsip Manajemen, penerjemah J-Smith D.F.M. Jakarta: PT Bumi Aksara.

Tjiptono, Fandy. (2014). Pemasaran Jasa Prinsip, Penerapan, dan Penelitian, Yogyakarta : Andi Offset,. 